\title{
The Methodological Centre for the Documentation, Conservation, and Restoration of Musical Instruments \\ Tereza Žürková
}

In 2020, four years will have passed since the establishment of the Methodological Centre for the Documentation, Conservation, and Restoration of Musical Instruments (MCMI), ${ }_{1}$ which was founded as part of the musical instruments department of the Czech Museum of Music in 2016. In reality, however, this is a much older project on which the staff of the Czech Museum of Music had been doing preparatory work for many years. The project's goal is to secure expert care for the historical musical instruments in the collections of memory institutions in the Czech Republic, meaning their expert documentation, evaluation of their condition, and proposing and realising appropriate conservation and restoration work.

Musical instruments are the subject of research for a specialised discipline of musicology organology. Specialised procedures are required for studying and evaluating musical instruments, and the same applies to the principles of caring for instruments and to the rules for their handling. The goal of the MCMI is to establish standards of expert care for historical musical instruments and to apply them to concrete collections. The concept of the MCMI is built to some extent upon the experiences of other methodology centres in the Czech Republic, but as its primary methodological basis, it follows the standards of the CIMCIM, ${ }^{2}$ the international project MIMO, ${ }^{3}$ and other specialised texts. The area of interest covers all types of musical instruments with a primary focus on the instruments traditionally used in European musical culture. ${ }^{4}$

1) Methodological Centre for the Documentation, Conservation, and Restoration of Musical Instruments [online]. Accessed from: http://www.mcmi.cz [accessed on 2 Sept. 2020].

2) Comité international pour les musées et collections d'instruments et de musique (International Committee for Museums and Collections of Instruments and Music) [online]. Accessed from: http://network.icom. museum/cimcim [accessed on 2 Sept. 2020].

3) Musical Instrument Museums online [online]. Accessed from: http://www.mimo-international.com/ MIMO [accessed on 2 Sept. 2020].

4) Also of importance, if secondarily, are instruments of European folk culture and of non-European musical culture, which occur in Czech collections in disproportionally smaller numbers. In addition, these groups require a special approach with respect both to documentation and to conservation and restoration. 


\section{Goal of the project and key activities}

Since its inception, the MCMI has been operating on two levels:

a) through contacts (by collaborating mainly with museums and memory institutions to which it provides the expert evaluation of musical instrument collections both with respect to documentation and from the perspective of the evaluation of the condition of instruments and the proposal of their subsequent care);

b) as a non-contact information portal for the given field (mainly through the website monitoring of breaking news in the field, collecting texts by experts, creating specialised databases, building up a specialised library available to the public at the reading room of the Czech Museum of Music etc.).

The primary task of the project is to create a methodology for the documentation, conservation, and restoration of musical instruments, which constitutes expert support to interested institutions and to individuals in the field of the proper evaluation, documentation, and treatment of historical musical instruments and from the perspective of the principles of the proper handling of musical instruments. Methodologies are formed gradually as general rules and as specific requirements for individual families of instruments. The contents are then divided into four subgroups:

a) methodologies of documentation: these strive to standardise the documentation process for individual groups of musical instruments by creating documentation forms and methodological instructions for their completion. In this area, there is also great emphasis on the question of digitisation of musical instruments, which is now viewed as a key task, the goal of which is:

- the digital storage of cultural content and of its current condition, which may have a limited lifespan (conservation of the object in digital form);

- the possibility of facilitating general contactless access to digitised material (protection of sensitive objects from damage caused by frequent handling) regardless of where it is kept (making the maximum quantity of information about an object accessible to the public at large and to the expert community);

- more efficient collection management (records and identification of objects).

b) methodologies of preventive conservation: these define the basic conditions required for the material and structural stability of musical instruments, so as to prevent or reduce to a minimum their degradation (this involves direct, contactless work with the object);

c) methodologies of conservation: these determine the methods of basic treatment of the object by direct procedures involving contact, the goal of which is stabilisation of the object's functional condition;

d) methodologies of restoration: these describe the difficult process of expert work on instruments leading to the restoring of their original appearance (and/ or function) by defining specific procedures that respect the technical, sonic, and artistic structure of the original. 
The purpose of these methodologies is to create a clear, comprehensible guide to replace the need for personal consultation with experts on basic documentation, the evaluation of an object's condition, and the proposal of appropriate care for historical musical instruments. The goals of the project are the precise determination of the numbers of musical instruments in Czech collections and their condition, and the securing of appropriate care so as to prevent or minimise their degradation, ensuring that any work on conservation or restoration is carried out in an appropriate manner.

Other activities of the MCMI are:

- expert processing of musical instruments in Czech collections;

- consultation and advice on documentation, conservation, and restoration of musical instruments;

- work on the conservation and restoration of musical instruments;

- digitisation of historical musical instruments;

- providing independent expert
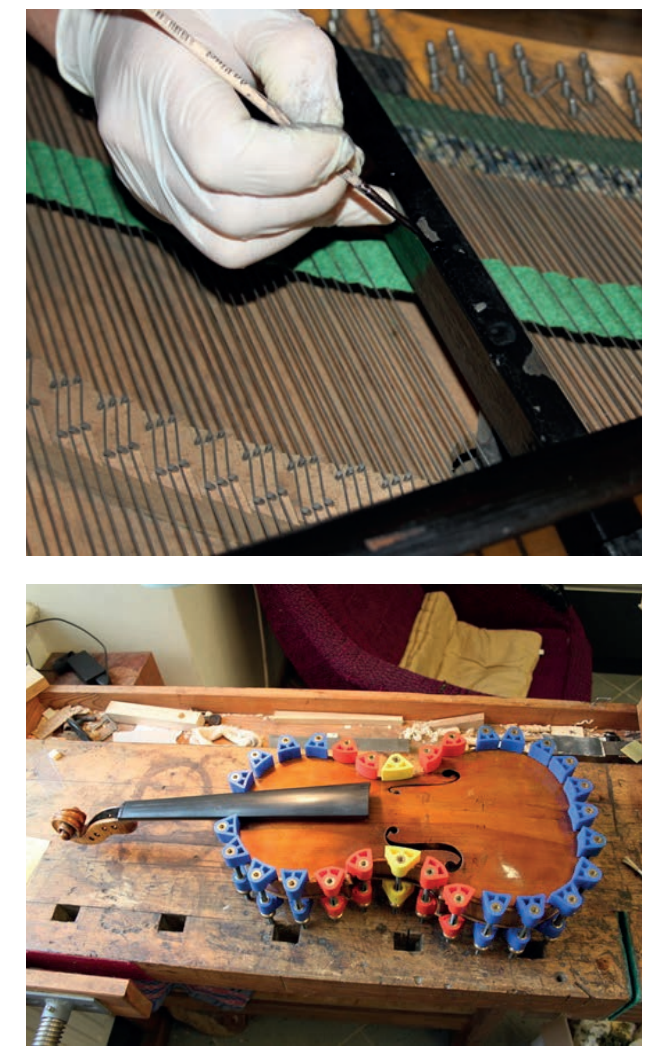

Restoration work in progress / Průběh restaurátorských prací

evaluations in the areas of documentation / conservation / restoration (including determination of proper routines for caring for collections of musical instruments and the evaluation of climatic and lighting conditions);

- creating auxiliary resources for the documentation of musical instruments (databases of instruments / databases of manufacturers accessible from the MCMI website);

- cooperation with other methodology centres and specialised institutions in the Czech Republic and abroad;

- building up a specialised library accessible to the public and of an electronic library accessible from the MCMI website;

- educational service and promotion (consultations, seminars, conferences, website). 


\section{Database of the MCMI}

Besides expert methodologies, the MCMI will gradually publish data on its website in two specialised databases:

a) database of musical instruments: on the basis of methodologies and consultations, the goal of the MCMI is to gain information from the institutions involved about the historical musical instruments in their collections and to present this information within the framework of a single database, which can be a useful platform not only for scholars, but also for the institutions themselves;

b) database of manufacturers of musical instruments: this presents a summary of information about musical instrument makers primarily of Czech origin or about foreign manufacturers who spent some time in the Czech lands or settled here permanently. The database strives to be as comprehensive as possible, so it presents basic information about the manufacturer as well as all other pieces of information that could contribute towards further research about that manufacturer. Most of the entries come from a hard-copy database kept at the department of musical instruments of the Czech Museum of Music, which has been built up over several decades by the department's curators, and to which new persons and institutions are still being added as they are discovered by the latest research and literature.

In view of the fact that the database is to serve primarily as a tool in support of organological research and not as a conventional lexicographical work, the development of the methodology has been guided by several specific characteristics. The publishing of the database is divided into three successive tasks: 1) the first task consists of the digitisation of the existing hard-copy database, which was comprehensively and systematically updated until the 1980s (in later years, research and updates focused on individuals and not on the database as a whole); 2) a follow-up step is the processing of the data in the database into the form of encyclopaedia entries (this involves not just the formal editing of the text, but also the verifying of the listed sources); 3 ) the final step is the gradual updating of the individual entries based on the latest findings of research and literature and the addition of new entries based on the findings of the latest research. The publication of the existing (i.e. not newly updated) form of the database is justified given the possibility of the relatively prompt publication of data and in particular the volume of information that the existing database contains. Even in this form, it represents a very important source of organological research. Making updates based on the latest discoveries as a follow-up step is a very time-consuming task, so it will be carried out gradually.

Entries are structured on two levels: at the first level an entry gives basic information about a manufacturer that is of fundamental importance from the perspective of organology (differentiated by bold font), then on the second level is all additional information of a less fundamental nature, but which may contribute towards the finding of new sources of information about the manufacturer. This two-level conception together with the 
open-ended content of the entries offers users a comprehensive service and constantly updated research about the person in question.

The database of manufacturers is linked to the database of instruments, and with the processing of the instrument database, this will gradually enable users both to study information about manufacturers and to study specific preserved instruments from their workshops.

\section{Conclusion}

Musical instruments are an integral and very important part of our country's cultural heritage. One goal of a memory institution is therefore to collect, document, and care for these instruments. Because musical instruments often embody a combination of different materials and techniques, caring for them is a highly specialised field. Today, these historical objects are preserved and presented mostly as visual artefacts, but their original musical function must not be overlooked by treating them merely as artefacts of the visual arts or artistic craftsmanship.

One must remember that restoration is an intervention that always reduces to some extent the overall historical value of the original, for which the object is being preserved. Memory institutions should prioritise preventive conservation over performing work directly on an object. The rigorous application of the principles of preventive conservation means stopping the destruction of a musical instrument and gaining enough time for an expert evaluation of the need for any conservation or restoration work. The goal of the MCMI is to establish standards of care for historical musical instruments so as to extend their lifespan as much as possible while reducing to a minimum any interventions that would be detrimental to their historical value.

Address: Tereza Žůrková, České muzeum hudby, Karmelitská 2, 11800 Praha 1, Czech Republic E-mail: tereza.zurkova@nm.cz 


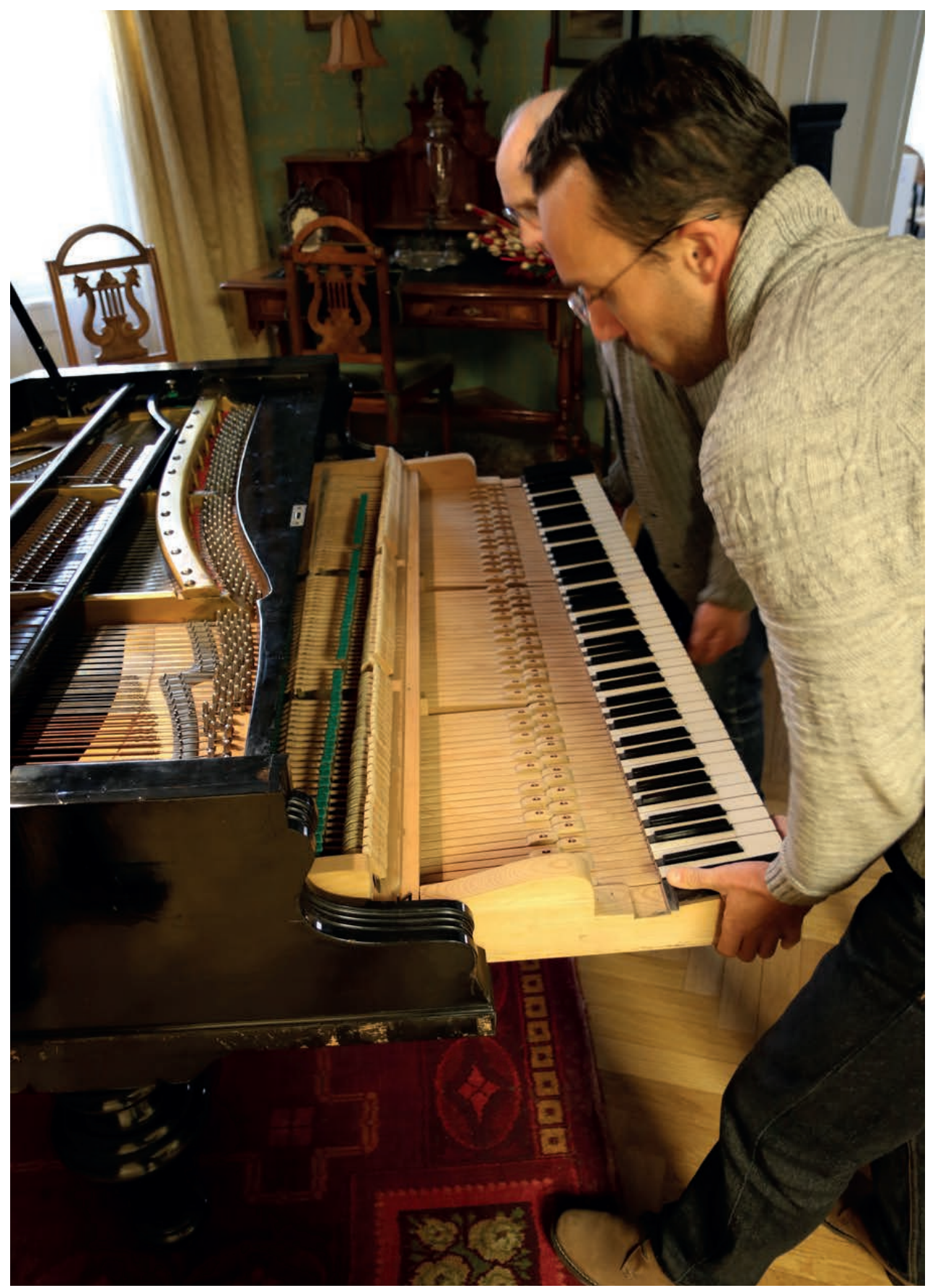

Examination and evaluation of the condition of Leoš Janáček's piano / Prohlídka a posouzení stavu klavíru Leoše Janáčka

Moravian Museum, Music History Department, Brno, 2016 /

Moravské zemské muzeum, Oddělení dějin hudby, Brno, 2016 


\section{Metodické centrum}

\section{dokumentace, konzervace}

\section{a restaurování}

hudebnich nástrojů

\section{Tereza Žirková}

V roce 2020 uplynuly čtyři roky od vzniku Metodického centra dokumentace, konzervace a restaurování hudebních nástrojů (dále jen MCMI), ${ }^{1}$ které bylo založeno př̀i oddělení hudebních nástrojủ Českého muzea hudby v roce 2016. Ve skutečnosti se však jedná o mnohem starší projekt, který pracovníci Českého muzea hudby připravovali po řadu let. Cílem tohoto projektu je zajištění odborné správy historických hudebních nástrojů ve sbírkách pamětových institucí v ČR, tj. jejich odborná dokumentace, posouzení stavu a navržení i realizace vhodných konzervátorských či restaurátorských zásahů.

Hudební nástroje jsou předmětem výzkumu specializované muzikologické disciplíny organologie. Jejich zkoumání a zhodnocení vyžadují odborné postupy. Totéž platí o zásadách jejich ošetření a také o pravidlech zacházení s nimi. Cílem MCMI je stanovit standardy odborné správy historických hudebních nástrojů a komplexně je aplikovat na konkrétní sbírky. Koncepce MCMI navazuje dílčím způsobem na zkušenosti dalších metodických center v České republice, metodologicky ale vychází především ze standardů CIMCIM, ${ }^{2}$ z mezinárodního projektu $\mathrm{MIMO}^{3}$ a dalších odborných textů. Předmětem zájmu jsou všechny typy hudebních nástrojủ, a to primárně nástroje tradičního instrumentáře evropské hudební kultury.

1) Metodické centrum dokumentace, konzervace a restaurování hudebních nástrojů [online]. Dostupné z: http://www.mcmi.cz [cit. 2. 9. 2020].

2) Comité international pour les musées et collections d'instruments et de musique (International Committee for Museums and Collections of Instruments and Music) [online]. Dostupné z: http://network.icom.museum/ cimcim [cit. 2. 9. 2020].

3) Musical Instrument Museums online [online]. Dostupné z: http://www.mimo-international.com/MIMO [cit. 2. 9. 2020].

4) Sekundárně též nástroje evropské lidové kultury a nástroje mimoevropské hudební kultury, které se v českých sbírkách vyskytují v nepoměrně nižším počtu. Tyto skupiny navíc vyžadují specifický přistup jak k dokumentaci, tak i ke konzervování a restaurování. 


\section{Cíl projektu a klíčové aktivity}

MCMI působí od počátku na dvou úrovních:

a) kontaktně (spoluprací zejména s muzejními a památkovými institucemi, kterým poskytuje odborné posouzení sbírek hudebních nástrojů jak z pohledu dokumentace, tak také z pohledu zhodnocení stavu nástrojů a navržení následné péče);

b) bezkontaktně jako informační portál v dané oblasti (zejména prostřednictvím webových stránek - sledováním aktualit v oboru, shromaždováním odborných textů, vytvářením odborných databází, budováním odborné knihovny přístupné veřejnosti prostřednictvím studovny Českého muzea hudby atd.).

Primárním úkolem projektu je tvorba metodik pro dokumentaci, konzervaci a restaurování hudebních nástrojů, která je odbornou podporou zainteresovaným institucím či jednotlivcům v oblasti správného zhodnocení, zdokumentování a ošetření historických hudebních nástrojů a z hlediska zásad správného zacházení s hudebními nástroji. Metodiky jsou vytvářeny postupně, jako obecná pravidla i jako specifické požadavky pro jednotlivé nástrojové skupiny. Obsahově jsou dále děleny do čtyř podskupin:

a) metodiky dokumentace: usilují o standardizaci dokumentačního schématu pro jednotlivé skupiny hudebních nástrojů tvorbou dokumentačních formulářů a metodických návodů pro jejich vyplnění. V rámci této oblasti je velký důraz kladen též na problematiku digitalizace hudebních nástrojů, která je vnímána v současné době jako klíčový úkol, jehož cílem je

- digitální uchování kulturního obsahu a jeho současného stavu, který může mít omezenou životnost (konzervace předmětu v digitální podobě);

- možnost zprostředkování všeobecného přístupu k digitalizovanému materiálu bezkontaktně (ochrana citlivých předmětů před poškozením v důsledku časté manipulace) a bez ohledu na místo jeho fyzického uložení (zpřístupnění maximálního množství informací o předmětu široké laické i odborné veřejnosti);

- zefektivnění správy sbírky (evidenční a identifikační zajištění předmětu).

b) metodiky preventivní konzervace: definují základní podmínky potřebné k materiálové i konstrukční stabilitě hudebních nástrojů tak, aby nedocházelo $\mathrm{k}$ jejich degradaci, resp. aby se jejich degradace snížila na minimum (jedná se o přímý, bezkontaktní zásah na předmětu);

c) metodiky konzervace: určují způsob základního ošetření předmětu přímým, tedy kontaktním zásahem, jehož cílem je stabilizace fyzického stavu předmětu;

d) metodiky restaurování: popisují náročný proces odborného zásahu na nástroji vedoucí k obnovení jeho původní podoby (případně též funkce) definicí specifických postupů, které respektují technickou, zvukovou a výtvarnou strukturu originálu.

Účelem těchto metodik je vytvořit jasný a srozumitelný návod, který nahradí osobní odborné konzultace při základní dokumentaci, posouzení stavu a navržení vhodné péče u historických hudebních nástrojů. Cílem projektu je přesné zjištění rozsahu a stavu hudebních 


\section{Tereza Žůrková}

nástrojů v českých sbírkách a zajištění vhodné péče tak, aby případná degradace byla zastavena nebo omezena na minimum a aby př́padné konzervátorské či restaurátorské zásahy byly provedeny vhodným způsobem.

Dalšími aktivitami MCMI jsou

- odborné zpracování hudebních nástrojů v českých sbírkách;

- konzultace a poradenství v oblasti dokumentace, konzervace a restaurování hudebních nástrojů;

- konzervátorsko-restaurátorské zásahy na hudebních nástrojích;

- digitalizace historických hudebních nástrojů;

- poskytování nezávislých odborných posouzení v oblasti dokumentace / konzervování / restaurování (včetně stanovení správného režimu zacházení se sbírkami hudebních nástrojů a hodnocení klimatických a světelných podmínek);

- tvorba pomocných prostředků pro dokumentaci hudebních nástrojů (databáze nástrojů / databáze výrobců dostupné z webu MCMI);

- spolupráce s ostatními metodickými centry a specializovanými institucemi v České republice i zahraničí;

- budování odborné knihovny přístupné veřejnosti a elektronické knihovny dostupné z webu MCMI;

- vzdělávací servis a propagace (konzultace, semináře, konference, web).

\section{Databáze MCMI}

Kromě odborných metodik na svých webových stránkách MCMI postupně zveřejňuje data ve dvou specializovaných databázích:

a) databázi hudebních nástrojů: záměrem MCMI je na základě metodik a konzultací získat od zainteresovaných institucí informace o historických hudebních nástrojích v jejich sbírkách a tyto informace prezentovat v rámci jediné databáze, která tak může být užitečnou platformou nejen pro badatele, ale i pro samotné instituce;

b) databázi výrobců hudebních nástrojů: přináší souhrn informací o výrobcích hudebních nástrojů převážně českého původu, nebo o výrobcích zahraničních, kteří v českých zemích určitý čas působili nebo se zde trvale usadili. Databáze usiluje o co největší komplexnost, proto uvádí kromě základních informací o výrobci rovněž veškeré dílčí získané informace, které by mohly přispět k dalšímu výzkumu osobnosti výrobce. Heslář vychází převážně z papírové databáze uložené v oddělení hudebních nástrojů Českého muzea hudby, která byla budována kurátory oddělení po několik desítek let, a je dále doplňován o nové osoby a instituce, jejichž existence vyplynula z poznatků novějšího výzkumu a literatury.

Vzhledem k tomu, že databáze má sloužit především jako podpůrný nástroj organologického výzkumu a nikoli jako konvenční lexikografické dílo, je metodika zpracování směřována několika specifičnostmi. Publikování databáze je rozděleno na tři navazující úkoly: 1) první krok spočívá v digitalizaci stávající papírové databáze, která byla komplexně systematicky 

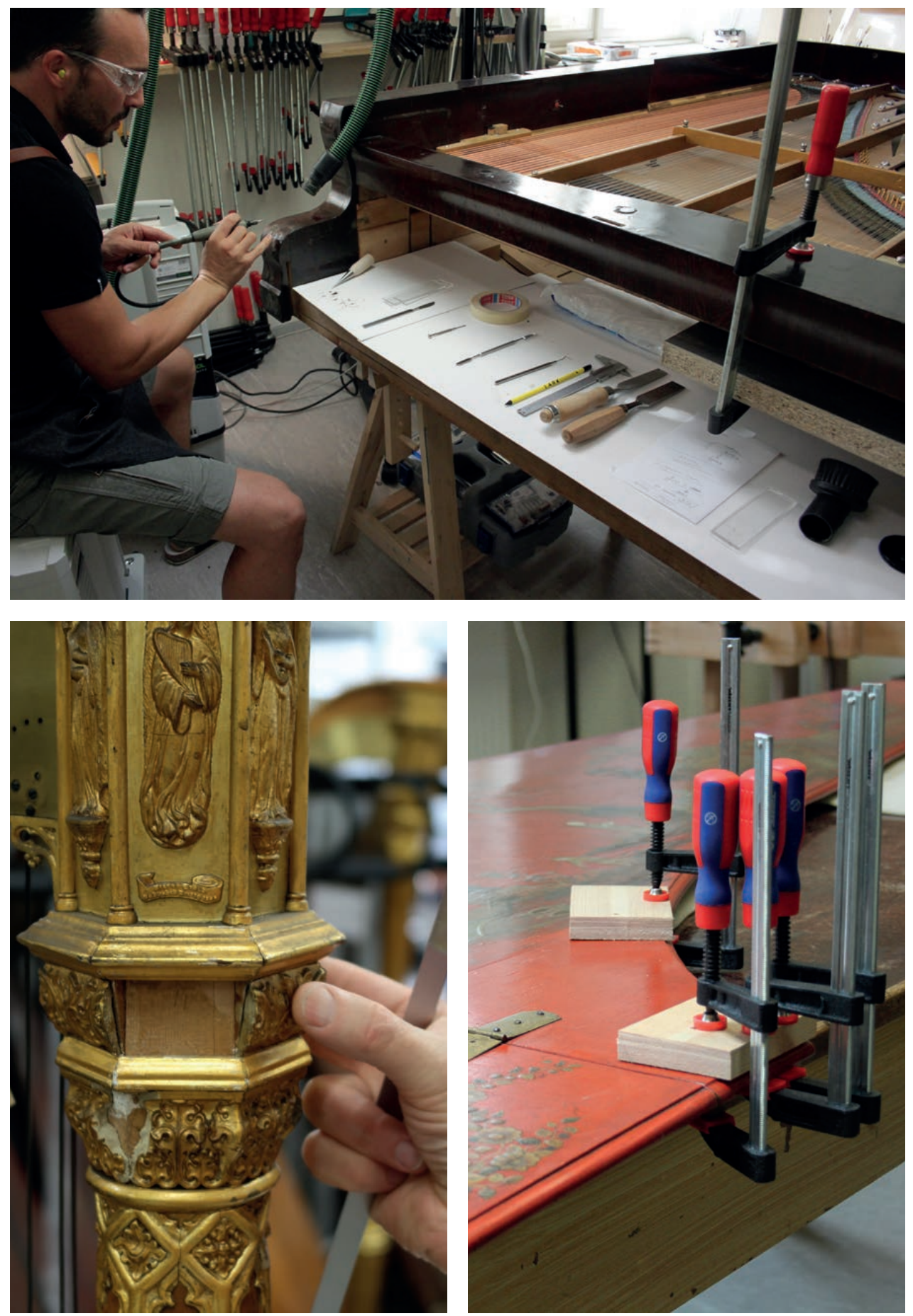

Restoration work in progress / Průběh restaurátorských prací 


\section{Tereza Žưrková}

aktualizována do osmdesátých let 20. století (v dalších letech byly výzkum a aktualizace zaměřeny na dílčí osobnosti, nikoli na databázi jako celek); 2) návazným krokem je zpracování dat této databáze do podoby slovníkových hesel (nejde jen o formální úpravu textu, ale též o ověření uvedených zdrojů); 3) finálním krokem je postupná aktualizace jednotlivých hesel dle poznatků nejnovějšího výzkumu a literatury a též rozšiření hesláře o nová hesla dle výsledků nejnovějších výzkumů. Zveřejnění stávající (tj. nově neaktualizované) podoby databáze je opodstatněno možností poměrně pohotového zveřejnění dat a zejména rozsahem informací, které tato stávající databáze obsahuje. I v této podobě totiž představuje velice významný zdroj organologického výzkumu. Aktualizace dle nejnovějších poznatků jako návazný krok je úkol časově náročný, proto bude naplňován postupně.

Struktura hesel je dvouúrovňová: v první úrovni uvádí heslo základní a z organologického hlediska zásadní informace o výrobci (typograficky odlišeno tučným fontem), v rámci druhé úrovně jsou uvedeny veškeré další dílčí informace i méně zásadního rázu, které však mohou přispět k nalezení nových zdrojů informací o výrobci. Toto dvouúrovňové pojetí společně s obsahovou otevřeností hesel přináší uživatelům servis komplexní a neustále aktuální rešerše o dané osobnosti.

Databáze výrobců je propojena s databází nástrojů, což bude postupně se zpracováním nástrojové databáze umožňovat uživatelům kromě studia informací o výrobci také studium konkrétních dochovaných nástrojů z jeho dílny.

\section{Závěr}

Hudební nástroje jsou nedílnou a velice významnou součástí kulturního dědictví naší země. Cílem pamětových institucí je proto tyto nástroje shromažd’ovat, dokumentovat a pečovat o ně. Péče o hudební nástroje je vzhledem k tomu, že předměty v sobě často kombinují různé materiály i techniky, značně specifická. Dnes jsou tyto historické předměty uchovávány a prezentovány převážně jako vizuální artefakty, nicméně nelze přehlížet jejich původní hudební funkci a zacházet s nimi pouze jako s předměty výtvarného umění či uměleckého řemesla.

Je nutno mít na paměti to, že restaurování je zásah, který vždy do určité míry redukuje komplexní historickou hodnotu originálu, pro kterou je předmět uchováván. Pamětové instituce by měly vždy preferovat preventivní konzervaci před přímým zásahem na předmětu. Důsledná aplikace zásad preventivní konzervace znamená zastavení destrukce hudebního nástroje a získání dostatečného množství času pro odborné posouzení případných konzervátorských či restaurátorských zásahů. Cílem MCMI je stanovit standardy v péči o historické hudební nástroje tak, aby u nich bylo dosaženo co nejdelší životnosti za předpokladu co nejmenších zásahů eliminujících jejich historickou hodnotu.

\footnotetext{
Adresa: Tereza Žůrková, České muzeum hudby, Karmelitská 2, 11800 Praha 1, Česká republika E-mail:tereza.zurkova@nm.cz
} 